\title{
OD STRATEGII UNII EUROPEJSKIEJ NA RZECZ AFRYKI DO STRATEGICZNEGO PARTNERSTWA Z AFRYKĄ - DYLEMATY O REALNEJ WIZJI WSPÓEPRACY
}

Unia Europejska rozwija swoje zdolności do działania na arenie międzynarodowej. Proces przenoszenia kompetencji do prowadzenia polityki zagranicznej na szczebel instytucji Unii Europejskiej jest bardzo dynamiczny. Efekty zmian, konsekwencje procesu, widoczne są zwłaszcza w relacjach z najbliższymi sąsiadami. Afryka, to kontynent, który stanowi dla wielu państw członkowskich obszar szczególnego zainteresowania. Od początku kształtowania Europejskiej Wspólnoty Gospodarczej relacje gospodarcze z państwami afrykańskimi wpisywały się w ramy funkcjonowania tej organizacji. Polityczny wymiar relacji kształtował się w miarę wprowadzania kolejnych zmian w materię traktatową. W obszarze tych dwóch podstawowych wymiarów, politycznego i gospodarczego, widoczne jest kilka płaszczyzn wzajemnych interakcji: Unia Europejska a poszczególne państwa afrykańskie, Unia Europejska a grupy państw afrykańskich, Unia Europejska a Unia Afrykańska/NEPAD. Na ten obraz nakładają się także bilateralne powiązania państw Unii z państwami afrykańskimi.

Podczas szczytu w dniach 15-16 grudnia 2005 roku Rada Europejska przyjęła dokument „Strategia Unii Europejskiej na rzecz Afryki: Europejsko-afrykański pakt na rzecz przyspieszenia rozwoju Afryki" (ang. EU Strategy for Africa: Towards a Euro-African pact to accelerate Africa's development) ${ }^{1}$. Stanowił on wyraz koordynacji polityki Unii wobec Afryki, traktowanej jako kontynent, na rzecz którego podejmowane są określone działania. Strategia była zatem wyrazem skonsolidowanego podejścia UE do kreowania polityki skierowanej wobec całego kontynentu afrykańskiego. Uwzględniała ona zarówno relacje na płaszczyźnie powiązań z organizacjami międzynarodowymi, jak i poszczególnymi państwami oraz grupami państw, obejmując szeroki wachlarz zagadnień w ramach wybranych dziedzin. W Strategii zawarto postanowienia dotyczące współpracy z Unią Afrykańską i poszczególnymi państwami afrykańskimi w celu m.in: budowania pokoju oraz walki z terroryzmem i handlem bronią; pobudzania wzrostu gospodarczego; rozwoju edukacji i ochrony zdrowia; ochrony praw człowieka. Przyjęty dokument miał być odpowiedzią na potrzeby kontynentu afrykańskiego, przy założeniu, że polityka Unii wobec Afryki przyczyni się do osiagnnięcia milenijnych celów rozwoju określonych przez ONZ w 2000 roku, takich jak walka

1 Projekt tej strategii został przedstawiony w ramach Komunikatu Komisji Europejskiej dla Rady, Parlamentu Europejskiego i Komitetu Ekonomiczno-Społecznego z 12 października 2005 roku: Strategia Unii Europejskiej na rzecz Afryki: Europejsko-afrykański pakt na rzecz przyspieszenia rozwoju Afryki, 12.10.2005, $\operatorname{COM}(2005) 489$. 
z ubóstwem, głodem, chorobami, degradacją środowiska ${ }^{2}$. Strategia była podstawą do podjęcia działań w kierunku utworzenia ram strategicznego partnerstwa Unii Europejskiej i Afryki, co zostało potwierdzone na drugim i trzecim szczycie UE-Afryka w 2007 i 2010 roku.

Celem artykułu jest analiza mechanizmu wdrażania postanowień Strategii dla Afryki, jak i dokumentów, na podstawie których stworzono ramy i rozwijano partnerstwo strategiczne do roku 2010. Szczególna uwaga skupiona zostanie na próbie określenia oddziaływania tych dokumentów oraz uwarunkowań związanych z możliwością ich efektywnego wdrażania. Prowadzone działania w ramach UE, jak i jej poszczególnych państw członkowskich, pozwalają na wskazanie obszarów, gdzie widoczne są efekty współpracy na linii Unia Europejska-Afryka, jak i te, gdzie realizacja zapisów staje się fikcją. Tak ujęte zagadnienie pozwoli na wstępną ocenę realizacji partnerstwa strategicznego i przedstawienie wniosków dotyczących perspektywy kreowania polityki UE wobec Afryki.

\section{OD KAIRU DO LIZBONY}

Relacje na linii Unia Europejska-Afryka zostały formalnie zapoczątkowane podczas pierwszego szczytu, który miał miejsce w Kairze 3-4 kwietnia 2000 roku. Uczestniczyło w nim 66 delegacji państw afrykańskich i europejskich. Od tego momentu możemy mówić o ramach dialogu politycznego w oparciu o przyjęte rozwiązania instytucjonalne, które przybrały postać regularnych spotkań ministrów i wyższych rangą urzędników ${ }^{3}$. W deklaracji oraz przyjętym na tym szczycie planie działania, znalazły się istotne zobowiązania polityczne i gospodarcze w następujących obszarach: regionalnej współpracy gospodarczej; integracji Afryki w ramy światowej gospodarki; praw człowieka, zasad demokracji, dobrego rządzenia; budowy pokoju i zapobiegania konfliktom; rozwoju (walka z biedą, edukacja, zdrowie, środowisko, bezpieczeństwo

2 W 2000 roku 189 szefów rządów i państw zaakceptowało Deklarację milenijną ONZ zawierającą 8 celów, które mają zostać zrealizowane do 2015 roku. Wśród nich znalazły się: redukcja ubóstwa i głodu, zapewnienie równego statusu kobiet i mężczyzn, poprawy stanu zdrowia, poprawy stanu edukacji, walki z AIDS, ochrony środowiska naturalnego, a także zbudowania globalnego partnerstwa między narodami na rzecz rozwoju. Realizacja Milenijnych Celów Rozwoju jest monitorowana. Jednym z założeń deklaracji jest redukcja o połowę światowego poziomu ubóstwa. Przyczynić się do tego miało przekazywanie na pomoc rozwojową przynajmniej $0,7 \%$ PKB. Podczas konferencji ONZ w Meksyku w 2002 roku, Unia Europejska zadeklarowała, że mogłaby zwiększyć swoją oficjalną pomoc rozwojową do $0,33 \%$ PKB do 2006 roku. W 2009 roku pomoc UE wynosiła 49 mld euro, co odpowiada $0,42 \%$ unijnego PKB. UE jest nadal daleko od realizacji przejściowego wspólnego celu, zakładającego przeznaczenie na pomoc 0,56\% DNB do 2010 roku i 0,7\% do roku 2015. Komisja Europejska ogłosiła rok 2010 Europejskim Rokiem Walki z Ubóstwem i Wykluczeniem Społecznym. Patrz także: Raport ONZ dotyczący Milenijnych Celów Rozwoju na rok 2009 oraz Raport Sekretarza Generalnego ONZ, opublikowany w marcu 2010 roku, Keeping the promise: a forward-looking review to promote an agreed action agenda to achieve the Millennium Development Goals by 2015.

3 Pierwsze spotkanie ministerialne miało miejsce 11 października 2001 roku w Brukseli. Drugie spotkanie z 28 listopada 2002 roku odbyło się w Ouagadougou w Burkina Faso. Na spotkaniu przyjęto deklarację potępiającą terroryzm oraz przygotowano plan działania przeciwdziałający handlowi ludźmi. 
żywnościowe $)^{4}$. Wśród postanowień szczytu za istotne uznaje się też te dotyczące zwrotu skradzionych dóbr kultury z byłych kolonii oraz ustępstwa na rzecz redukcji zadłużenia zewnętrznego państw Afryki ${ }^{5}$. Na kairskim szczycie zaproponowano nowy mechanizm, który przyczynić miał się do implementacji planu działania. Opierał się on o spotkania na szczeblu głów państw i rządów (szczyty UE-Afryka), a także spotkania ministerialne (między szczytami) oraz spotkania biregionalnej grupy (ang. a Bi-regional group at senior Officials' level).

Szczyt miał być nowym otwarciem w relacjach międzykontynentalnych, odejściem od postrzegania relacji w perspektywie dziedzictwa kolonialnego. Wcześniejsze próby nawiązania stosunków w ramach Partnerstwa Eurośródziemnomorskiego czy Europejskiej Polityki Sąsiedztwa, a także w oparciu o Porozumienie z Cotonou, zaowocowały nawiązaniem dialogu z grupami państw afrykańskich, nie był on jednak skoordynowany i spójny, a także nie obejmował państw całego kontynentu.

Istotne dla dalszych działań Unii było utworzenie w 2001 roku Nowego Partnerstwa dla Rozwoju Afryki (NEPAD) i w 2002 roku przekształcenie, które zaowocowało powstaniem Unii Afrykańskiej (UA). Afryka weszła na drogę integracji. Zauważalne stały się procesy skupiające państwa afrykańskie wokół organizacji regionalnych. W Afryce, $\mathrm{z}$ dużym trudem, wyłonił się nowy, kluczowy partner w relacjach międzynarodowych, Unia Afrykańska, która miała aspiracje by stać się aktorem politycznym wyrażającym wspólne zdanie państw afrykańskich. Narodziny Unii Afrykańskiej i NEPAD są znakiem, iż przywódcy afrykańscy są zdeterminowani by przejąc kontrolę i odpowiedzialność za zmiany w Afryce ${ }^{6}$. Te wydarzenia odcisnęły piętno na przygotowaniach do kolejnego, drugiego w historii, szczytu UE-Afryka. Planowany na 2003 rok szczyt zostaje przesunięty w czasie ${ }^{7}$. Stanowi to przyczynek dla politycznego rozczarowania obu stron. Komisja Europejska nadal jednak prowadzi dialog z poszczególnymi państwami afrykańskimi, jak i Unią Afrykańską. 12 października 2005 roku Komisja Europejska przyjmuje projekt unijnej strategii na rzecz Afryki, pod hasłem Europejsko-afrykańskiego paktu na rzecz przyspieszenia rozwoju Afryki ${ }^{8} .17$ listopada $2005 \mathrm{r}$. Parlament Europejski przyjął rezolucję w sprawie Strategii rozwoju dla Afryki (2005/2141). Podczas szczytu grudniowego w 2005 roku Rada Europejska zatwier-

4 Szerzej patrz: Cairo Declaration, Cairo Plan of Action 2000, Africa-Europe Summit Under the Aegis of the $O A U$ and the EU, Cairo, 3-4 April 2000, 107/4/00 REV4, 106/4/00 REV 4.

${ }_{5}$ Podczas szczytu państwa afrykańskie koncentrowały się na zagadnieniach związanych z zadłużeniem i dostępem do rynków UE, delegacje unijne naciskały na zagadnienia związane z nielegalną imigracją, brakiem demokracji i rządów prawa, walce $\mathrm{z}$ handlem narkotykami.

6 Już podczas spotkania ministerialnego w Burkina Faso 28 listopada 2002 przedstawiciele państw UE zapowiedzieli, iż będą traktować UA jako przedstawiciela/reprezentanta interesów państw afrykańskich. Szerzej patrz: Annex 3, EU platform on future relations between Africa and the EU, Africa-Europe Ministerial Meeting, Ouagadougou, Burkina Faso, 28 November 2002, 19996/02, Presse 378.

7 Pierwotnie szczyt miał odbyć się w Lizbonie 4-5 kwietnia 2003 roku. W pierwszej połowie roku 2003 prezydencję sprawowała Grecja. Do przesunięcia daty szczytu przyczyniły się głównie spory dotyczące udziału w nim prezydenta Zimbabwe, Roberta Mugabe.

${ }^{8}$ Komisja przyjmuje komunikat w sprawie strategii UE na rzecz Afryki przy okazji wspólnego spotkania z Komisją UA. Z formalnego punktu widzenia warto zaznaczyć, że nie ma on charakteru wspólnej strategii. 
dziła poprawioną, zawartą w jej komunikacie, propozycję Komisji, co skutkowało przyjęciem strategii UE na rzecz Afryki ${ }^{9}$. Strategia stworzyła jednolite ramy dla wszystkich państw UE oraz potwierdziła, że rozwój Afryki stanowi jeden z głównych priorytetów politycznych UE. Strategia obejmowała krajową, regionalną i panafrykańską płaszczyznę partnerstwa. Jej celem było stworzenie kompleksowych, zintegrowanych i długoterminowych ram współpracy UE z kontynentem afrykańskim. Na jej podstawy złożyły się dwa założenia:

- bez praworządności, bezpieczeństwa i pokoju nie jest możliwe osiagnięcie trwałych postępów w zakresie rozwoju;

- integracja regionalna, regionalna wymiana handlowa oraz połączenia regionalne stanowią czynniki niezbędne do wspierania rozwoju gospodarczego.

Strategia określała ramy działań instytucji europejskich, jak i poszczególnych państw członkowskich w odniesieniu do Milenijnych Celów Rozwoju ONZ, gdzie konieczne jest większe wsparcie w obszarach mających bezpośredni wpływ na standard życia, takich jak opieka zdrowotna, edukacja i bezpieczeństwo żywności ${ }^{10}$. W strategii znalazła się także propozycja podpisania umów o partnerstwie gospodarczym UE-regiony Afryki oraz ustanowienie partnerstwa UE-Afryka w zakresie infrastruktury, którego celem będzie wsparcie transafrykańskich programów budowy sieci transportowych, energetycznych, komunikacyjnych i kanalizacyjnych.

Warto wskazać na dodatkowe założenie, które wyrażono w Komunikacie Komisji „Strategia UE na rzecz Afryki: Europejsko-afrykański pakt na rzecz przyspieszenia rozwoju Afryki” przez stwierdzenie, iż „kluczem do sukcesu partnerstwa będzie umiejętność scementowania związków pomiędzy dwoma kontynentami ponad formalnym wzajemnym oddziaływaniem politycznym i gospodarczym. Jednym z istotnych składników tego szeroko zakrojonego dialogu jest zapoczątkowanie partnerstw bliźniaczych zbliżających afrykańskie i europejskie uniwersytety i szkoły, parlamenty, miasta, gminy, przedsiębiorstwa i przemysł, związki zawodowe, sieci społeczeństwa obywatelskiego oraz muzea" 11 .

Pierwsze lata po wejściu w życie strategii były sprawdzianem dla Unii. To w jaki sposób i w jakim zakresie uda jej się zrealizować jej zapisy miało zdeterminować dalsze działania na kontynencie afrykańskim. Warto podkreślić, iż strategia została opracowana bez przeprowadzenia szeroko zakrojonych konsultacji. Dokument ten miał charakter jednostronny. To z pewnością zaburzało rodzące się partnerstwo i wpływało na odbiór działań przygotowywanych w jej oparciu. Widoczna nierówność partnerów

9 Warte odnotowania są także inne rozpoczęte w 2005 roku przedsięwzięcia i inicjatywy międzynarodowe dotyczące Afryki. Na szczycie G8 w Gleneagles podjęto zobowiązania dotyczące oddłużenia i pomocy rozwojowej dla Afryki. Rada UE przyjęła także pakiet zobowiązań na rzecz państw rozwijających się, w tym państw afrykańskich, w celu zwiększenia pomocy publicznej na rzecz rozwoju - ODA oraz poprawy efektywności pomocy i spójności polityki na rzecz rozwoju w osiaggnięciu milenijnych celów rozwoju do 2015 roku.

10 To założenie wzmacniają i uzupełniają cele realizowane w ramach porozumienia z Cotonou, TDCA, partnerstwa eurośródziemnomorskiego oraz Europejskiej Polityki Sąsiedztwa.

${ }_{11}$ Komunikat Komisji Europejskiej..., op. cit. Patrz także: Opinia Europejskiego Komitetu Ekonomiczno-Spolecznego z 18 sierpnia 2006 roku w sprawie: Konieczność priorytetowego traktowania Afryki: punkt widzenia europejskiego społeczeństwa obywatelskiego, 2006/C 195/25. 
na płaszczyźnie gospodarczej, jak i politycznej wpływała na postrzeganie Unii jako dawcy wsparcia, Afryki jako jej odbiorcy. Istotne jest także to, iż strategia przypieczętowała działania wewnątrz Unii, czyli przeniesienie na aparat instytucjonalny Unii tych zadań, które wcześniej rozkładały się na poszczególne państwa członkowskie. To kolejny wyraz pogłębiania integracji $\mathrm{w}$ ramach polityki zagranicznej Unii.

W pierwszym okresie realizacji strategii zauważalne było wyodrębnienie poziomu politycznego i operacyjnego. Polityczne zaangażowanie opierało się na wskazanych w strategii zasadach. Operacyjne zaangażowanie to wsparcie infrastruktury, jak i działań na rzecz pokoju (np. misja AMIS w Darfurze) w ramach Afrykańskiego Funduszu na rzecz Pokoju (APF), programu UA Nyerere - na rzecz szkolnictwa wyższego, w tym wymiany studenckiej, a także włączenia w ramy unijnego programu Erasmus Mundus $^{12}$ afrykańskich uniwersytetów. Strategia Unii miała znaczenie dla próby stworzenia wrażenia przejrzystości w działaniach na rzecz Afryki i zwiększenia spójności polityki unijnej poprzez koordynację działań Komisji Europejskiej i państw członkowskich na rzecz Afryki. Spójność działań unijnych najbardziej widoczna była w obszarze polityki rozwojowej. Państwa członkowskie UE, kolejny raz, nie stawiały przeszkód w przerzuceniu odpowiedzialności za pomoc państwom afrykańskim na szczebel wspólnych instytucji w oparciu o wspólny budżet. Takie podejście mimo wszystko korzystnie zaowocowało. Koordynacja zapobiega dublowaniu działań i ogranicza koszty zarządzania pomocą. Działania wspólne odbijają się większym echem w środowisku międzynarodowym, często taka promocja zwiększa oddziaływanie wsparcia. W Komunikacie Komisji z 27 czerwca 2007 roku stwierdzono, że „Strategia ta okazała się użyteczna: jako ramy polityczne/acquis oraz jako proces polityczny. Dzięki niej UE stała się lepszym, bardziej zjednoczonym i efektywnym partnerem, a w przyszłości strategia ta nadal będzie kluczowym dokumentem politycznym, przy czym jest to dopiero początek"13.

Strategia była bodźcem dla kolejnych działań. Na piątym spotkaniu ministrów UE i Afryki w grudniu 2005 roku w Bamako, w Mali, potwierdzono konieczność przeniesienia partnerstwa między UE a Afryką na nowy strategiczny poziom. Jego wyrazem miała być wspólnie przygotowana strategia UE i Afryki. Miała ona określać partnerstwo Unii z Afryka, a nie pozostawać jak wcześniej na poziomie jednostronnej strategii Unii na rzecz Afryki. W ramach tego nowego partnerstwa strategicznego Afryka czyli afrykańskie państwa i organizacje miały wziąć na siebie odpowiedzialność za swoją

12 Program Erasmus Mundus (Erasmus Mundus External Cooperation Window) został powołany decyzją Parlamentu Europejskiego i Rady (Decyzja nr 2317/2003/EC z 5 grudnia 2003 roku) na okres 5 lat (1.01.2004-31.12.2008). Obecnie trwa kolejna edycja programu na lata 2009-2013. Celem programu było wsparcie współpracy akademickiej, podniesienie jakości europejskiego szkolnictwa wyższego poprzez szerszą współpracę z państwami trzecimi i wspieranie w ten sposób mobilności studentów i kadry akademickiej oraz promowanie dialogu i zrozumienia między kulturami. Typy działań w ramach Erasmus Mundus realizowanego w latach 2009-2013 to: dofinansowanie dla wspólnych studiów prowadzonych przez konsorcja uczelni (wspólne studia Mundusowe); realizację projektów partnerskich wspierających mobilność między uczelniami z państw Unii Europejskiej i uczelniami z określonych obszarów geograficznych (Erasmus Mundus Joint Programmes).

${ }^{13}$ Komunikat Komisji do Parlamentu Europejskiego i Rady. Od Kairu do Lizbony - Partnerstwo strategiczne między UE i Afryka, Bruksela, 27 czerwca 2007, KOM(2007) 357. 
przyszłość polityczną i rozwój. Stosunki państw Unii i państw afrykańskich miały docelowo opierać się w większym stopniu na równości. To nowe podejście nie wpłynęłoby na zakres i wielkość pomocy rozwojowej, w celu zapewnienia realizacji milenijnych celów rozwoju w Afryce. Wypracowane w Bamako stanowisko zostało potwierdzone na szczycie Rady Europejskiej w grudniu 2006 roku oraz na szczycie Unii Afrykańskiej w styczniu 2007 roku.

Proces przygotowania wspólnej strategii wymagał dwustronnych konsultacji na różnych szczeblach. Uzgodnienia dotyczące celów i priorytetów politycznych wypracowywano podczas wspólnych spotkań. Strona unijna była reprezentowana przez Komisję, Sekretariat Rady i następujące po sobie prezydencje (niemiecką, portugalską i słoweńską). Unia Afrykańska była reprezentowana przez Komisję UA, a także państwa przewodniczące UA. W uzgodnieniach aktywnie angażowały się także państwa koordynujące kwestie polityczne $\mathrm{w}$ ramach dialogu kairskiego ${ }^{14}$. Wstępny projekt wspólnej strategii przyjęto w Brukseli na spotkaniu ministrów 15 maja 2007 roku. W proces konsultacji zaangażowali się przedstawiciele Parlamentu Europejskiego, Parlamentu Panafrykańskiego, a także partnerzy społeczno-gospodarczy. Uruchomiono specjalną stronę internetową ${ }^{15}$.

\section{OD LIZBONY DO TRYPOLISU}

W Lizbonie w dniach 8-9 grudnia 2007 roku przywódcy państw i rządów UE i Afryki ${ }^{16}$ przyjęli wspólną strategię Afryka-UE (ang. Joint Africa-EU Strategy - JAES) oraz plan działania na lata 2008-2010 na rzecz wdrażania partnerstwa strategicznego Afryka-UE ${ }^{17}$. Na szczycie zaakceptowano także deklarację lizbońską, w której państwa afrykańskie i europejskie wyraziły, iż „w uznaniu naszych dążeń oraz wszystkiego, co nas łączyło i łączy, jesteśmy zdecydowani budować nowe, strategiczne partnerstwo polityczne przyszłości, wychodzące poza utarte role darczyńców i odbiorców oraz oparte na wspólnych wartościach i celach w dążeniu do pokoju i stabilności, demokracji i praworządności, postępu i rozwoju"18. Szczyt rozpoczęła polityczna

14 Wśród tych państw: Algieria (pokój i bezpieczeństwo); Egipt (dobra kultury); Nigeria (zadłużenie); Senegal (migracja); Tunezja (pomoc); Libia (bezpieczeństwo żywności); Maroko (środowisko naturalne); Republika Południowej Afryki (handel i integracja regionalna).

15 Strona internetowa http://www.europafrica.org pomocna była w zbieraniu informacji od europejskich i afrykańskich podmiotów pozarządowych.

16 W szczycie uczestniczyło 70 szefów państw i rządów. Przyjazd na szczyt prezydenta Roberta Mugabe był powodem bojkotu spotkania przez premiera Wielkiej Brytanii Gordona Browna. Pomysł bojkotu poparły inne państwa europejskie: Czechy, Dania, Holandia, Szwecja. Jednakże z grona wspierających bojkot ostatecznie na szczyt nie przyjechał tylko premier Czech, Mirek Topolanek. Głównym przeciwnikiem bojkotu była sprawująca prezydencję Portugalia wspierana przez Niemcy. Na uwagę zasługuje fakt, iż po stronie prezydenta Zimbabwe stanęły państwa Unii Afrykańskiej. Dla wielu z nich motywem poparcia była niechęć do tworzenia precedensu, który pozwoliłoby w przyszłości wykluczyć z obrad inne państwo afrykańskie.

17 Wspólna strategia Afryka-UE i jej pierwszy plan działania (2008-2010), Bruksela, 3 marca 2008, 7204/08.

18 Deklaracja lizbońska - szczyt UE-Afryka, Lizbona, 8-9 grudnia 2007. 
deklaracja José Sokratesa, premiera Portugalii, która sprawowała w tym okresie prezydencję, w której potwierdził, iż „ten szczyt jest szczytem między równymi. Jesteśmy tu wszyscy równi”. Obrady podczas szczytu, prowadzone podczas pięciu zamkniętych sesji plenarnych, dotyczyły: pokoju i bezpieczeństwa, demokracji i praw człowieka, handlu i rozwoju, zmian klimatycznych i energii, migracji i zatrudnienia. Szczyt lizboński był okazją do pokazaniem siły zaangażowania państw Unii w Afryce w obliczu zwiększania wpływu w tym regionie innych państw, w szczególności Chin. Na mocy wspólnej strategii szefowie państw i rządów europejskich i afrykańskich zainicjowali wspólne strategiczne partnerstwo UE-Afryka. Miało ono przyczynić się do umożliwienia realizacji wspólnych strategicznych celów w ramach zarysowanych wspólnych interesów, wykraczających poza zakres polityki rozwojowej. Działania podejmowane miały być w ramach ośmiu partnerstw tematycznych: pokój i bezpieczeństwo, demokratyczne sprawowanie rządów i prawa człowieka; handel, integracja regionalna; milenijne cele rozwoju; energia; zmiana klimatu; migracje, mobilność i zatrudnienie; nauka, społeczeństwo informacyjne i przestrzeń kosmiczna ${ }^{19}$.

W ramach Partnerstwa Afryka-Unia Europejska na rzecz pokoju i bezpieczeństwa założono powiązanie działań politycznych, celów operacyjnych i finansowania. We wspólnej strategii stwierdza się, że Afryce należy pomóc w ponoszeniu obciążeń związanych z realizacją operacji pokojowych ${ }^{20}$. Podjęto konkretne działania na rzecz zwiększenia wsparcia finansowego i technicznego mającego na celu poprawę zdolności UA do planowania, prowadzenia i zarządzania operacjami pokojowymi, które wymagają dalszego wzmocnienia ${ }^{21}$.

Celem Partnerstwa Afryka-Unia Europejska na rzecz demokratycznego sprawowania rządów i praw człowieka było wypracowanie wspólnego rozumienia zasady demokratycznego sprawowania rządów oraz promowanie i konsolidacja wspólnego planu działania na rzecz praw człowieka. W tym obszarze warto wspomnieć tzw. proces rezerwy motywacyjnej, w ramach której 2,7 mld euro zostało przyznane tym państwom, które przygotuja plany działań na rzecz demokratycznego sprawowania rządów. To partnerstwo obejmuje również wzmacnianie współpracy w dziedzinie

19 Realizację partnerstw tematycznych Afryka-UE powierzono 8 unijnym zespołom ds. realizacji, obejmującym zaangażowane państwa członkowskie, Komisję i sekretariat Rady, i podlegającym ogólnej koordynacji ze strony grupy roboczej Rady ds. Afryki. Po stronie afrykańskiej brakuje odpowiedników unijnych zespołów ds. realizacji, aby móc wdrażać poszczególne partnerstwa i koordynować ich działalność. Rolę wiodącą odgrywa Komisja UA. Wsparcia jej mogłyby udzielić regionalne wspólnoty gospodarcze oraz Afrykański Bank Rozwoju.

${ }^{20}$ W roku 2007-2008 dyskusje polityczne dotyczyły kryzysów w Afryce, takich jak kryzys w Kenii, Mauretanii, Zimbabwe, Somalii, Darfurze, prowadzona przez UA misja pokojowa w Republice Środkowoafrykańskiej oraz misja wojskowa w ramach WPZiB w Czadzie.

${ }^{21}$ Instrument na rzecz pokoju w Afryce to środki finansowe wyodrębnione z Europejskiego Funduszu Rozwoju, zgodnie z decyzją o finansowaniu instrumentu na rzecz pokoju w Afryce przez EFR, podjętą przez Radę w dniu 11 kwietnia 2006 roku. Rada zatwierdziła zasadę finansowania instrumentu na rzecz pokoju w Afryce ze środków wewnętrznych AKP na kwotę nieprzekraczającą $300 \mathrm{mln}$ euro, na okres początkowy 2008-2010. W trzecim roku przeprowadzona zostanie wszechstronna ocena, obejmująca przegląd warunków oraz możliwości wykorzystania alternatywnych źródeł przyszłego finansowania, w tym środków finansowych przeznaczonych na Wspólną Politykę Zagraniczną i Bezpieczeństwa. 
kultury. W 2009 roku stworzono spis aktywności w dziedzinie dóbr kultury, który będzie stanowił podstawę podjęcia działań w tej dziedzinie. Warte zauważenia są dwie uwagi Parlamentu Europejskiego wyrażone w rezolucji z 24 marca 2009 roku. W pierwszej, apeluje o większe poparcie dla obecnych afrykańskich inicjatyw, takich jak Afrykański Mechanizm Wzajemnej Oceny (APRM), który stanowi dotychczas najpoważniejszy krok państw afrykańskich w kierunku poprawy rządów na kontynencie ${ }^{22}$. W drugiej, wyraża poważne zaniepokojenie tym, że plany sprawowania rządów opracowane przez Komisję dla każdego z krajów AKP, które będą podstawą programowania pomocy rozwojowej w kwocie dodatkowych 2700 milionów euro w ramach 10 Europejskiego Funduszu Rozwoju, zostały przygotowane bez żadnego udziału tych państw i zauważa, że kwalifikowalność do korzystania z dodatkowych środków jest oceniana na podstawie zestawu kryteriów, z których tylko jedno jest bezpośrednio powiązane z milenijnymi celami rozwoju. Parlament przyznał, że przygotowane przez Komisję Europejską plany grożą spłyceniem procesu Afrykańskiego Mechanizmu Wzajemnej Oceny.

Celem Partnerstwa Afryka-Unia Europejska na rzecz handlu i integracji regionalnej jest przyśpieszenie utworzenia większych i zintegrowanych regionalnie rynków oraz poprawa i utrwalenie infrastruktury i usług w Afryce. Priorytetem w tym obszarze stało się dotrzymanie zobowiązania do dostarczania do 2010 roku co najmniej 2 miliardów euro rocznie w charakterze ,,pomocy na rzecz handlu”, której największa część musi być przeznaczana dla Afryki. Punktem zapalnym w tym obszarze są umowy o partnerstwie gospodarczym. Partnerstwo Afryka-UE w dziedzinie infrastruktury powołano w 2007 roku, przed przyjęciem wspólnej strategii, a jego realizacja rozpoczęła się w 2008 roku. Celem partnerstwa jest zwiększenie unijnych inwestycji w infrastrukturę w Afryce, a co za tym idzie poprawa połączeń infrastrukturalnych pomiędzy poszczególnymi krajami afrykańskimi. Zastosowane instrumenty to: KPI/RPI w ramach 10 EFR (wsparcie transportu regionalnego, korytarzy energetycznych i komunikacyjnych, instrumentu energetycznego i funduszu wodnego); Fundusz powierniczy na rzecz infrastruktury (mechanizm dotacji i pożyczek).

W ramach partnerstwa Afryka-Unia Europejska na rzecz milenijnych celów rozwoju wskazano cztery kierunki działań: zagwarantowanie finansowania i wsparcia politycznego umożliwiającego osiągnięcie milenijnych celów rozwoju; przyśpieszenie osiągnięcia milenijnych celów rozwoju dotyczących bezpieczeństwa żywnościowego; przyśpieszenie osiagnięcia milenijnych celów rozwoju dotyczących ochrony zdrowia; przyśpieszenie osiąnnięcia milenijnych celów rozwoju dotyczących edukacji. Największym wyzwaniem pozostaje realizacja zobowiązań w dziedzinie zdrowia ${ }^{23}$.

22 Rezolucja Parlamentu Europejskiego Rok po szczycie w Lizbonie: aktualny stan partnerstwa Afryka-UE, Strasburg, 24 marca 2009, 2008/2318 (INI).

23 We wnioskach i zaleceniach zawartych w sprawozdaniu Europejskiego Trybunału Obrachunkowego ze stycznia 2009 roku w sprawie pomocy rozwojowej KE dla służby zdrowia w Afryce subsaharyjskiej podkreślono konieczność zwiększenia pomocy dla sektora zdrowia w Afryce subsaharyjskiej w kontekście zaangażowania w osiaganie milenijnych celów rozwoju związanych ze zdrowiem $\mathrm{w}$ ramach $10 \mathrm{EFR}$. 
Priorytetem Partnerstwa Afryka-Unia Europejska na rzecz energii jest integracja regionalna i modernizacja infrastruktury energetycznej, promowanie warunków sprzyjających inwestycjom w sektorze prywatnym, poprawa dostępu do usług energetycznych, zrównoważone wykorzystywanie potencjału Afryki w dziedzinie energii ze źródeł odnawialnych, poprawa efektywności energetycznej i zmniejszenie liczby odpadów. Istniejące instrumenty finansowe i programy tematyczne finansują projekty $\mathrm{w}$ tej dziedzinie (np. instrument energetyczny, dwustronne i regionalne programy EFR, program ENRTP).

Partnerstwo Afryka-Unia Europejska na rzecz zmian klimatycznych obejmuje dwa powiązane ze sobą działania priorytetowe: opracowywanie wspólnej polityki jeżeli chodzi o zmiany klimatu i współpracę w tej dziedzinie; przeciwdziałanie degradacji ziemi uprawnej i coraz częstszemu występowaniu suszy.

Partnerstwo Afryka-Unia Europejska na rzecz migracji, mobilności i zatrudnienia opiera się na deklaracji z Trypolisu Afryka-UE, planie działań Afryka-UE w sprawie handlu ludźmi oraz deklaracji i planie działań z Wagadugu w sprawie zatrudnienia i zmniejszenia ubóstwa w Afryce. Celem Partnerstwa jest stworzenie większej liczby lepszych miejsc pracy w Afryce, realizacja programu godnej pracy i lepsze zarządzanie przepływami migracyjnymi. Obszar ten był kluczowym dla wielu państw europejskich, stawiającym czoła falom migrantów. W jego ramach Komisja Europejska wspiera budowę sieci obserwatoriów migracyjnych w Afryce subsaharyjskiej i proponuje ustanowienie dialogu z afrykańską diasporą w Europie i wspieranie jej udziału w rozwoju Afryki. We wspólnej strategii potwierdzono, iż UE i UA uważa diasporę za swój szósty region. Na uwagę zasługuje wsparcie Centrum Informacji i Zarządzania Migracją (CIGEM) w Mali w zakresie jego innowacyjnych działań. Ponadto programy Erasmus Mundus, Tempus, Nyerere, Edulink, Młodzież w działaniu wpływać mają na mobilność afrykańskich studentów. W obszarze tym nie znalazły się odniesienia do nowego unijnego systemu tzw. niebieskich kart, zniechęcającego do wyjazdu wykwalifikowanych pracowników z państw rozwijających się w sektorach, w których te kraje mają niedobór siły roboczej.

Partnerstwo Afryka-Unia Europejska na rzecz nauki, społeczeństwa informacyjnego i przestrzeni kosmicznej ma umożliwić zmniejszenie luki w technologiach cyfrowych i badaniach naukowych pomiędzy Afryką a Europą, wzmocnienie afrykańskich zdolności w dziedzinie nauki, technologii teleinformatycznych i technologii kosmicznych oraz ich zastosowań, jak również do ich intensywniejszego wykorzystania jako ważnych czynników umożliwiających zmniejszanie ubóstwa, pobudzanie wzrostu gospodarczego i rozwoju społecznoekonomicznego. Partnerstwo zapewni wsparcie dla skonsolidowanego planu działań w dziedzinie nauki i technologii w Afryce oraz afrykańskiego regionalnego planu działania na rzecz gospodarki opartej na wiedzy ARAPKE. Komisja UA zaproponowała, aby w ramach tego partnerstwa zrealizować 19 projektów. W zakresie przestrzeni kosmicznej rozpoczęto pracę nad współpracą w obszarze unijnej inicjatywy KOPERNIKUS ${ }^{24}$.

${ }^{24}$ Proces ten rozpoczął się w trakcie nieformalnego spotkania Komisji Europejskiej i Komisji UA dotyczącego inicjatywy KOPERNIKUS, które odbyło się w Akrze (Ghana) w dniach 4-6 października 2008 roku. 
Komisja Europejska, sekretariat Rady i Komisja Unii Afrykańskiej zobowiązały się, że będą corocznie publikować sprawozdanie z postępów w realizacji wspólnej strategii i planu działan ${ }^{25}$.

\section{UZGODNIENIA Z TRYPOLISU}

W dniach 29-30 listopada 2010 roku w Trypolisie odbył się trzeci szczyt Unia Europejska-Afryka. Szczyt odbywał się pod hasłem „Inwestycje, wzrost gospodarczy i tworzenie miejsc pracy". Jego obrady zdominowała tematyka dotycząca migracji, energii, zmian klimatycznych i rolnictwa, bezpieczeństwa żywnościowego, integracji regionalnej, infrastruktury, technologii informacyjnych, nauki, przestrzeni powietrznej i kosmicznej ${ }^{26}$. Zauważalna na szczycie była nieobecność niektórych szefów państw i rządów reprezentujących największe państwa członkowskie Unii Europejskiej ${ }^{27}$. Uwagę zwracała także nieobecność przedstawicieli Sudanu ${ }^{28}$ i obecność oskarżanego przez społeczność międzynarodową o łamanie praw człowieka prezydenta Zimbabwe, Roberta Mugabe.

Szczyt był okazją do dyskusji nad osiagnięciami partnerstwa strategicznego UE-Afryka i przyszłymi priorytetami współpracy w ramach partnerstwa ${ }^{29}$. W przeddzień szczytu Josě Manuel Barroso stwierdził, że „,...obecnie przyszedł czas na umocnienie i pogłębienie naszych więzi oraz czerpanie z niespożytkowanego dotychczas potencjału w stosunkach między UE a Afryką. Silniejsza i bardziej intensywna współpraca przyczyni się znacząco do rozwoju Afryki i będzie miała istotne znaczenie dla osiągnięcia milenijnych celów rozwoju. Partnerstwo przedstawia również dla Europy prawdziwą wartość i stanowi szansę, której nie można nie wykorzystać. Dzięki niemu możemy pogłębić więzi z kontynentem zyskującym na znaczeniu w świecie, który jest

25 W trakcie spotkania ministrów w ramach tzw. trojki 16 września 2008 roku przyjęto pierwsze sprawozdanie z realizacji wspólnej strategii i planu działań. Patrz także: Komunikat Komisji dla Rady $i$ Parlamentu Europejskiego. Rok po szczycie w Lizbonie: aktualny stan partnerstwa Afryka-UE, Bruksela, 17.10.2008, KOM (2008)617.

${ }_{26}$ Prace w grupach odbywały się w następujących obszarach tematycznych: integracja regionalna, infrastruktura, TIK, nauka oraz rozwój sektora prywatnego; energia i zmiana klimatu; milenijne cele rozwoju, rolnictwo i żywność; pokój i bezpieczeństwo; rządy i prawa człowieka; migracja, mobilność i tworzenie miejsc pracy.

${ }^{27}$ W szczycie uczestniczyło 80 przedstawicieli państwa i rządów. Ponadto stronę unijną reprezentowali przewodniczący Rady Europejskiej Herman Van Rompuy, przewodniczący Komisji Europejskiej Josě Manuel Barroso oraz komisarz ds. rozwoju Andris Piebalgs.

28 Władze Sudanu nie uważają się za związane deklaracjami złożonymi w Trypolisie przez szefów państw i rządów o wdrożeniu wszystkich elementów porozumienia pokojowego z 2005 roku, w tym referendum dotyczącym podziału Sudanu, zaplanowanego na styczeń 2011 roku.

${ }_{29}$ Warta podkreślenia jest zbieżność daty szczytu z otwarciem przez Komisję Europejską debaty dotyczącej walki z ubóstwem. Publiczna konsultacja przyszłości unijnej polityki rozwojowej ma wpłynąc na zapisy Komunikatu w sprawie zmodernizowanej unijnej polityki rozwojowej, którą Komisja ma przedłożyć w 2011 roku. Patrz: Zielona Ksiega: Polityka rozwojowa Unii Europejskiej na rzecz wzrostu sprzyjajacego właczeniu społecznemu i zrównoważonemu rozwojowi - zwiększenie skuteczności polityki rozwojowej UE. 
w coraz większym stopniu oparty na współzależnościach"30. Na szczycie omówiono wspólną strategię współpracy i podsumowano I Plan Działania przyjęty podczas poprzedniego szczytu. Przedstawiciele Komisji Europejskiej swoje wystapienia oparli na wcześniej opublikowanych wnioskach ${ }^{31}$. Na szczycie wielokrotnie podkreślano potrzebę wyciągnięcia wniosków z trudności, jakie wystapiły przy realizacji pierwszego planu działań na lata 2008-2010. Przyjęty w Trypolisie II Plan Działania na lata 2011-2013 wraz z deklaracją polityczną szczytu może być traktowany jako wartość dodana w stosunku do umowy z Kotonu i Unii dla Śródziemnomorza. Z pewnościąjest on wyrazem ambitnych założeń, którym sprostać będzie jeszcze trudniej niż w przypadku I Planu. Spektakularnym fiaskiem szczytu okazało się nieprzyjęcie wspólnej deklaracji w sprawie zmian klimatycznych ${ }^{32}$. Na szczycie nie zajęto się także istotną kwestią dla bezpieczeństwa żywnościowego, czyli nabywaniem przez zagranicznych inwestorów, przy poparciu rządów państw afrykańskich, gruntów rolnych w Afryce, jak i też sprawą eksportu minerałów z regionów dotkniętych konfliktem ${ }^{33}$. Nadal, pomimo niechęci państw afrykańskich, widoczne były naciski przedstawicieli na zawarcie umów o partnerstwie gospodarczym ${ }^{34}$.

Warte podkreślenia jest to, iż politycznym deklaracjom, po raz kolejny wyrażonym w Trypolisie, nie towarzyszy spójny plan finansowy. W rezolucji z 15 grudnia 2010 roku w sprawie przyszłości strategicznego partnerstwa Afryki i Unii Europejskiej po trzecim szczycie UE-Afryka Parlament Europejski wzywa do „zapisania EFR w budżecie w celu zapewnienia parlamentarnej kontroli nad wykorzystaniem poszczególnych europejskich instrumentów finansowych w realizacji poszczególnych rodzajów partnerstwa, 35 .

Szczyt w Trypolisie trudno uznać za przełom w relacjach między dwoma kontynentami w oparciu o nową wizję działań na rzecz zrównoważonego rozwoju w Afryce. Proces zmian w Afryce determinowany jest wsparciem sąsiada europejskiego, któremu coraz trudniej stworzyć wspólną strategię polityczną i zobowiązać się do dalszej pomocy finansowej z uwagi na problemy wynikające z kryzysu finansowego w Europie. Brak chęci do gry zespołowej widać po obu stronach. Szczyt nadal traktowany jest jako

30 Szczyt Unia Europejska-Afryka: łaczymy wysiłki na rzecz zwiększenia inwestycji, wzrostu gospodarczego $i$ tworzenia miejsc pracy, Press Releases, RAPID, Bruksela, 25.11.2010.

31 Communication on the consolidation of EU-Africa relations, European Commiossion, Brussels, 10.11.2010.

32 Wicepremier Waldemar Pawlak, przewodniczący polskiej delegacji na tym szczycie stwierdził, iż „Kraje afrykańskie uznały ją za mało śmiałą, a UE w tym Polska nie mogła zaakceptować daleko idących propozycji zmian".

33 Nielegalna eksploatacja kopalin minerałów wpływa na eskalację wojen i konfliktów. W Parlamencie Europejskim postulowano rozpoczęcie działań legislacyjnych przez Komisję w celu zapewnienia wykrywalności minerałów przywożonych na rynek UE. Podobne regulacje przyjęto w Stanach Zjednoczonych przez ustawę o minerałach z regionów ogarniętych konfliktami.

${ }_{34}$ O korzyściach i zagrożeniach dla państw afrykańskich związanych z przyjęciem umów o partnerstwie gospodarczym szerzej patrz: K. Kołodziejczyk, Umowy o partnerstwie gospodarczym (EPA) w stosunkach Unia Europejska-grupa państw AKP, ISM UW, Zeszyt 16, Warszawa 2010, s. $114-122$.

${ }^{35}$ Rezolucja Parlamentu Europejskiego z dnia 15 grudnia 2010 roku w sprawie przyszłości strategicznego partnerstwa Afryki i Unii Europejskiej po trzecim szczycie UE-Afryka, Strasburg, P7_TA(2010)0482. 
miejsce do zadbania o własne interesy w oparciu o bilateralne rozgrywki i regionalne roszady polityczne. Tłem spotkania staje się przedstawienie przez organy reprezentujące UE i UA kolejnej odsłony propozycji na rzecz strategicznego partnerstwa.

Dokonując wstępnej analizy ośmiu partnerstw po szczycie warto zwrócić uwagę na następujące elementy:

- uznanie dużego znaczenia integracji regionalnej dla wzrostu i rozwoju, podkreślając w szczególności zawarte w oświadczeniu z Trypolisu zobowiązanie do osiąnięcia pełnej operacyjności afrykańskich ram pokoju i bezpieczeństwa w ścisłej współpracy z organizacjami regionalnymi (Partnerstwo - Pokój i bezpieczeństwo);

- zainicjowanie działań na rzecz walki z nielegalną eksploatacją kopalin w Afryce, napędzającą wojny domowe i konflikty przez identyfikowalność minerałów przywożonych na rynek UE i uwzględnienie Inicjatywy Przejrzystości Przemysłu Wydobywczego (EITI) na wzór amerykańskich regulacji o minerałach $\mathrm{z}$ regionów ogarniętych konfliktami (Partnerstwo - Pokój i bezpieczeństwo);

- wezwanie wraz z Parlamentem Panafrykańskim do ratyfikacji Karty Unii Afrykańskiej w sprawie demokracji, wyborów i sprawowania rządów (Partnerstwo - Demokratyczne rządy i prawa człowieka);

- skierowanie do afrykańskich przywódców apelu przewodniczącego Rady Europejskiej Hermana Van Rompuya o wsparcie Międzynarodowego Trybunału Karnego (Partnerstwo - Demokratyczne rządy i prawa człowieka);

- porozumienie UE-UA w sprawie nawiązania dialogu politycznego w celu znalezienia rozwiązania wspólnych obaw dotyczących umów o partnerstwie gospodarczym (Partnerstwo - Handel, integracja regionalna i infrastruktura);

- zainicjowanie powstania ram prawnych i fiskalnych sprzyjających stymulowaniu wzrostu gospodarczego i przyciągającego bezpośrednie inwestycje zagraniczne (Partnerstwo - Handel, integracja regionalna i infrastruktura);

- zobowiązanie do opracowania pakietów bardziej zdecydowanych działań wspierających regionalne wspólnoty gospodarcze oraz poprawę infrastruktury na całym kontynencie afrykańskim (Partnerstwo - Handel, integracja regionalna i infrastruktura);

- odnowienie zobowiązania państw Unii Europejskiej, że do 2015 roku przeznaczać będą na oficjalną pomoc rozwojową $0,7 \%$ PKB, co ma zasadnicze znaczenie dla osiągnięcia milenijnych celów rozwoju do 2015 roku (Partnerstwo - Milenijne cele rozwoju);

- przyjęcie programu współpracy państw Afryki i UE w dziedzinie odnawialnych źródeł energii (Partnerstwo - Energia) ${ }^{36}$;

- zobowiazanie UE do przekazania w latach 2010-2012 7,2 mld euro na szybkie rozpoczęcie projektów i inicjatyw z zakresu zmian klimatu, przy czym znaczna część tych środków ma być udostępniona Afryce (Partnerstwo - Zmiany klimatu);

- rozszerzenie istniejących programów mobilności studentów i pracowników naukowych, a także takich inicjatyw, jak uniwersytet panafrykański (Partnerstwo - Migracja, mobilność i zatrudnienie);

36 Przewodniczący Komisji Europejskiej J. M. Barroso wezwał do przeprowadzenia w Afryce zielonej rewolucji w sektorze energetyki. 
- nawiązanie dialogu naukowo-technicznego na szczeblu wysokich urzędników i ministerstw w celu udoskonalenia ram współpracy naukowo-technicznej (Partnerstwo - Nauka, społeczeństwo informacyjne i przestrzeń kosmiczna).

W pierwszej części Komunikatu Komisji do Parlamentu Europejskiego i Rady z 2007 roku, określającego partnerstwo strategiczne między Unią Europejską i Afryką, podkreśla się, że „Afryka znajduje się obecnie w centrum polityki międzynarodowej, jednak nowością jest fakt, iż Afryka, w szczególności zaś Unia Afrykańska, przestaje obecnie być omawiana w kontekście rozwoju, stając się samodzielnym partnerem politycznym. Jest coraz bardziej oczywiste, że Afryka jest ważna - jako głos polityczny, jako siła gospodarcza i jako ogromne źródło potencjału ludzkiego, kulturalnego, naturalnego oraz naukowego" ${ }^{\text {"37. }}$.

Unia Europejska jest na drodze, aby sąsiedztwo zmienić w realne partnerstwo. Nowe podejście do spraw afrykańskich zapoczątkowane spotkaniami na szczycie, które zaowocowały przyjęciem Strategii na rzecz Afryki, później partnerstwa strategicznego, i otwarciem dialogu euro-afrykańskiego wpisuje się w promocję Unii jako globalnego gracza i partnera w relacjach międzynarodowych. Dla Afryki i Unii Europejskiej korzystne jest skoordynowanie działań i inicjatyw w odpowiedzi na wyzwania, którym musi sprostać kontynent afrykański.

Unia Europejska jest uważana za największego donatora Afryki. Pomoc w ramach prowadzonej polityki humanitarnej i rozwojowej jest niewątpliwie istotnym wsparciem dla ludności państw afrykańskich, choć częstokroć o sukcesie wsparcia decyduje nie wielkość pomocy, lecz efektywność jej wdrożenia. Pomoc unijna w małym stopniu przyczynia się do rozwiązania problemów Afryki i wpływa na jej przyszłość, jest ona raczej wsparciem w próbie radzenia sobie z teraźniejszością. Kluczowa dla Afryki staje się odpowiedź na pytania na ile polityka prowadzona przez Unię Europejską wpływa na życie w państwach afrykańskich. To nie wysokość pomocy, ale wysokość dopłat do produktów rolniczych lub liberalne podejście w sprowadzaniu minerałów niezbędnych w produkcji europejskiej odgrywać może znaczenie w polityce rozwojowej. Strategiczne podejście, które uwzględnia wieloaspektowe spojrzenie na problemy Afryki W większym stopniu może przyczynić się do radzenia z nimi i być realną szansą pomocy na rzecz rozwoju.

Sytuacja w Afryce ma znaczenie dla państw Unii, gdyż jako sąsiad pośrednio odczuwają skutki konfliktów i biedy w Afryce. Dane statystyczne dotyczące migrantów afrykańskich, tych którzy dotarli do Europy i tych, którzy zginęli u jej granic są alarmujące. Współzależność Afryki i Europy jest w XXI wieku bardzo widoczna. W erze nowoczesnych technologii i komunikacji, gdzie przestrzeń się zaciera, czas nie odgrywa takiej samej funkcji, różnice międzykontynentalne stają się jeszcze bardziej zarysowane.

37 Komunikat Komisji do Parlamentu Europejskiego i Rady, Od Kairu do Lizbony-Partnerstwo strategiczne między UE i Afrykq, 27 czerwca 2007, Bruksela, COM(2007)357, s. 1. 
W odniesieniu do zmian dotyczących unijnej polityki zagranicznej, warte podkreślenia jest to, iż podstawowa kategoria ,,interes w relacjach międzynarodowych” nabiera nowego charakteru na płaszczyźnie Unii. Przykład prowadzenia polityki wobec Afryki to potwierdza. Nadal widoczny jest wielopoziomowy wymiar relacji Unia Europejska-Unia Afrykańska; Unia Europejska-państwa afrykańskie, Unia Europejska-grupy państw afrykańskich, państwa członkowskie UE-państwa afrykańskie. Strategiczne podejście jest próbą kompleksowego objęcia polityk Unii Europejskiej skierowanych wobec kontynentu afrykańskiego, a co za tym idzie zawiera się w tym podejściu wymiar relacji z poszczególnymi państwami afrykańskimi, grupami państw, jak i Unią Afrykańską pretendującą do reprezentowania interesów afrykańskich. Kompleksowe ujęcie widoczne jest także w zakresie przedmiotowym strategicznego partnerstwa, gdyż obejmuje ono sfery gospodarczą i polityczna, w ramach tematycznych partnerstw. Pomimo krótkiego okresu od momentu przyjęcia ram strategicznych, zauważalne są korzyści z prowadzenia działań w ramach poszczególnych partnerstw, co determinuje kolejne inicjatywy unijne na rzecz swojego sąsiedztwa afrykańskiego.

Poszczególne państwa członkowskie widzą konieczność i niezbędność zaangażowania aparatu instytucji unijnych w państwach i dziedzinach, którymi są zainteresowane. Zaawansowanie prac nad efektywnym mechanizmem decyzyjnym wspólnej polityki zagranicznej po traktacie lizbońskim, z pewnością będzie miało wpływ na tempo i jakość prowadzonej polityki UE w oparciu o ramy strategicznego partnerstwa.

Ze względu na różnorodność problemów afrykańskich, a także relacji poszczególnych państw członkowskich z państwami afrykańskimi, podejście regionalne będzie widoczne w działaniach Unii. Strategia ma uzupełniać, a nie zastępować działania podejmowane w ramach np. dialogu z afrykańskimi państwami basenu Morza Śródziemnego. Podejście strategiczne sprawia, że państwa poza ramami regionalnymi nie są wykluczone $\mathrm{z}$ dialogu.

Realizacja podejścia strategicznego będzie miała charakter długoterminowy. Zaangażowanie Unii w Afryce będzie ewaluować. Wiele zależy od rozwoju Unii Afrykańskiej i Unii Europejskiej oraz determinacji przywódców państw afrykańskich i europejskich, którzy będą stawiali czoła nie tylko problemom, które trapią Afrykę, ale także będą musieli sprostać odpowiedzi na problemy, które trapią Europę, np. problem migracji, wzrastające zapotrzebowanie na surowce energetyczne państw UE, w tym złoża nieodnawialnych źródeł energii znajdujące się w Afryce.

\section{STRESZCZENIE}

Afryka, to kontynent, który stanowi dla wielu państw członkowskich Unii Europejskiej obszar szczególnego zainteresowania. Od początku kształtowania Europejskiej Wspólnoty Gospodarczej relacje gospodarcze z państwami afrykańskimi wpisywały się w ramy funkcjonowania tej organizacji. Polityczny wymiar relacji kształtował się w miarę wprowadzania kolejnych zmian w materię traktatową. Podczas szczytu w dniach 15-16 grudnia 2005 roku Rada Europejska przyjęła dokument „Strategia Unii Europejskiej na rzecz Afryki: Europejsko-afrykański pakt na rzecz przyspieszenia rozwoju Afryki". Stanowił on wyraz skonsolidowanego podejścia UE do kreowania polityki skierowanej wobec całego kontynentu afrykańskiego. Strategia była podstawą do podjęcia działań w kierunku utworzenia ram strategicznego partnerstwa Unii Euro- 
pejskiej i Afryki, co zostało potwierdzone na II i III szczycie UE-Afryka w 2007 i 2010 roku. Celem artykułu jest analiza mechanizmu wdrażania postanowień Strategii dla Afryki, jak i dokumentów, na podstawie których stworzono ramy i rozwijano partnerstwo strategiczne do roku 2010. Szczególna uwaga skupiona została na próbie określenia oddziaływania tych dokumentów oraz uwarunkowań związanych z możliwością ich efektywnego wdrażania. Prowadzone działania w ramach UE, jak i jej poszczególnych państw członkowskich, pozwalają na wstępną ocenę realizacji partnerstwa strategicznego i przedstawienie wniosków dotyczących perspektywy kreowania polityki UE wobec Afryki.

\title{
FROM THE EU STRATEGY FOR AFRICA TO THE STRATEGIC PARTNERSHIP WITH AFRICA - DILEMMAS CONCERNING REAL VISION OF COOPERATION FOR PEACE
}

\begin{abstract}
Africa is subject of special interest for member states of the European Union. Since the beginning of the European Community, economical relations with African countries have been part of organization's functioning. Political aspect of those relations was a result of treaty amendments. During the summit of December 15-16, 2005, the EU Strategy for Africa was adopted by the European Council. The document was an example of comprehensive position of the European Union towards the African continent and served as a basis for the future strategic partnership between the European Union and Africa, confirmed during the second and the third summit of 2007 and 2010. The aim of this paper is to analise mechanisms of implementation of the EU Strategy for Africa. Attention will be paid to indicate the possibility and conditions of effective implementation and to evaluate effects of strategic partnership with Africa.
\end{abstract}



ARTUR WEJKSZNER

EWOLUGJA TERRORYZMU MOTYWOWANEGO

IDEOLOGIA RELIGIJNA

NA PRZYKKADZIE

SALAFICKIEGO RUCHU

GLOBALNEGO DŻHADU

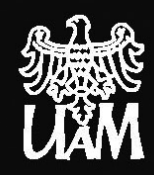

Wydawnictwo Naukowe WNPiD UAM

Poznań 2010 
